\title{
$\operatorname{arCOS} D E S I G N$
}

\section{O positivismo percebido nas etapas de desenvolvimento do DNA da marca}

Jan Raphael Reuter Braun (UFSC, Brasil)

jrrbraun@gmail.com

Faculdade SATC, Rua Pascoal Meller, 73

Criciúma, SC. CEP: 88.805-350

Dayane Lopes (UFSC, Brasil)

dayalvez@gmail.com

Leandro Werner (UFSC, Brasil)

makakowerner@gmail.com

Richard Perassi (UFSC, Brasil)

richard.perassi@uol.com.br

Luiz Salomão Ribas Gomez (UFSC, Brasil)

salodesigner@gmail.com 


\title{
O positivismo percebido nas etapas de desenvolvimento do DNA da marca
}

Resumo: O design caracterizou-se por utilizar constantemente de metodologias projetuais, o que, de certo modo, colaborou para a criação de inúmeros métodos disponíveis atualmente. Porém, a base científica que valida os processos e métodos, é constantemente questionada. Deste modo, a partir de uma visão positivista, buscou-se analisar as etapas de conceituação que fazem parte da metodologia projetual que vem sendo desenvolvida em um laboratório de Design da Universidade Federal de Santa Catarina para a criação de marcas.

Palavras-chave: Metodologia Projetual, Metodologia Científica, Design.

\section{The perceived positivism in the development stages of the brand DNA}

\begin{abstract}
Design has been characterized by constant use of project's methodologies, which, in some way, contributed to the creation of countless methods of projective design methodologies. However, the scientific basis which validates the processes and methods adopted, is constantly questioned. Thus, from a positivist view, we sought to examine the stages of conceptualization that are part of design methodology that has been developed in a laboratory of Design, Federal University of Santa Catarina to the creation of brands.
\end{abstract}

Key words: Project's methodologies, Scientific Methodology, Design. 


\section{Introdução}

As metodologias utilizadas pelo design, atualmente convergem para uma visão muito mais projetual do que propriamente científica, caracterizando o design como uma atividade onde a ciência geralmente caminha por experiências e métodos empíricos. Porém, percebe-se que os métodos e pesquisas científicas, tem ganhado cada vez mais espaço nos projetos de design. Uma das tarefas da pesquisa em design, de acordo com Bonsiepe é responder a questão sobre os fundamentos do design, pois, segundo o autor, não se pode dizer "que o design seja uma atividade destituída de fundamentos, vale dizer uma disciplina sem disciplina, ou se o design está baseado em fundamentos”, Neste sentido pode-se entender que o design é uma atividade que se baseia em fundamentos e premissas já estudas e desenvolvidas anteriormente, com base em materiais científicos e em experiências empíricas (BONSIEPE, 2011, p.111).

Ainda conforme Bonsiepe o desenvolvimento de pesquisas de cunho científico em design, ganham importância de maneira crescente primeiramente pelo fato da complexidade dos problemas, os projetos necessitam de respostas embasadas em fatos comprovados, Além disso, durante o projeto podem surgir novas questões que necessitam de novos conhecimentos advindos da pesquisa. Em segundo lugar, o autor aponta a expansão dos cursos de especialização na área, o que pressupõe a utilização de métodos de pesquisa científica para a "consolidação do ensino de design nas universidades, é necessário adaptar as tradições e estruturar acadêmicas” (вONSIEPE, 2011).

Assim, levando-se em consideração a necessidade de utilizar de métodos científicos no desenvolvimento de projetos, percebe-se que o design mais do que nunca volta-se a uma visão positivista, em que espera obter um resultado inquestionável ao fim do projeto a partir de comprovações científicas.

Este artigo apresenta como foco principal de estudo a análise da metodologia científica como base de sustentação a metodologia projetual que vem sendo desenvolvida em um dos laboratórios de Design, da universidade Federal de Santa Catarina. Para o desenvolvimento deste artigo primeiramente será realizada inicialmente uma pesquisa bibliográfica como embasamento aos conceitos e as relações entre os assuntos e posteriormente, será desenvolvida uma analise do processo de definição do DNA da marca, inserido na primeira etapa (Think) da metodologia тхм, Think, Experience e Manage. A escolha por somente esta etapa deve-se a sua relevância em relação ao processo de construção de identidade de marcas, servindo como base conceitual do projeto. 


\section{Design e metodologia}

De acordo com Bonsiepe (2011), a ciência do design surge junto ao ensino do mesmo, com os movimentos, De-Stijl e Bauhaus. Bürdek (2010), comenta que as metodologias para o design (projeto) foram criadas devido a crescente complexidade dos problemas e a necessidade de tratar os problemas além do modo intuitivo baseado nas experiências anterior.

Segundo Facca (2008, p.24) "para se projetar é necessário um método; algo que ajude a resolver o problema”, ou seja um caminho a prosseguir ou um modo de fazer para se chegar a um fim. Segundo a autora, o método é o procedimento, modo de agir ou a técnica, e metodologia é o estudo dos métodos. A autora diferencia a metodologia científica e a metodologia projetual, afirmando que a primeira é o estudo dos procedimentos metodológicos para a realização de um trabalho científico enquanto a segunda refere-se ao estudo dos procedimentos metodológicos utilizados no desenvolvimento de um projeto. Por procedimento metodológico, Facca (2008), afirma ainda que procedimento é o mesmo que o método.

Bonsiepe (2011), afirma que no design, tanto o ensino quanto a ciência apresentam o mesmo o foco da prática, ou seja, o projeto. Para o autor, a "ciências enxergam o mundo sob a perspectiva da cognição, as disciplinas do design o enxergam sob a perspectiva do projeto" e, embora haja uma movimento da prática do Design no sentido de uma aproximação ao mundo das ciências, o contrario ainda não é verdadeiro. Este fato somado a falta de interesse do mercado em desenvolver pesquisas por considerar um processo custoso e demorado, faz com que a ciência do Design seja deixada a cargo da academia (BONSIEPE, 2011).

Deste modo Bonsiepe (2011), sugere que uma ciência do design seja criada de modo a dar suporte à prática, não que seja necessário transformar o design em uma ciência, mas que ambas estejam integradas, e que no futuro o projeto possa também fazer parte das disciplinas científicas, pois mesmo em campos científicos existe o desenvolvimento de projetos.

\section{Positivismo}

O primeiro a utilizar o termo positivo foi Claude Henri de Saint-Simon de acordo com Iskandar e Leal (2011), "o raciocínio deveria se basear nos fatos observados e discutidos" negando assim o pensamento metafísico como explicação para os fenômenos. Os autores ainda afirmam que Augusto Comte, influenciado por Turgot, Condercet e Saint-Simon foi um dos precursores da linha de 
pensamento filosófico positivista que surgiu no século XIX onde, formalizou suas ideias positivistas ao afirmar que a "importância do conhecimento científico, não estava apenas defendendo uma orientação epistemológica, estava apresentando uma maneira de pensar e de realizar as transformações sociais”. Assim, o pensamento positivista segundo Iskandar e Leal (2000), "admite apenas o que é real, verdadeiro, inquestionável”, ignorando portanto as pesquisas científicas que não podem ser comprovadas ou não foram comprovadas.

Com auge no século XIX, as críticas às afirmações da metafísica e do cristianismo, em muito baseadas na crença teológica, começam a ser substituídas pelo dogmatismo científico. Verdan (1998) afirma que estas tendências tem sua maior expressão no positivismo.

Segundo Dutra (2005) o positivismo é considerado o opositor das doutrinas metafísicas, onde, de forma geral, seus seguidores aliam-se as ciências empíricas defendendo seus procedimentos baseados na observação e na experimentação. Ainda de acordo com o autor, os metafísicos alegam que os positivistas não entendem a verdadeira natureza das coisas pois "vivem de aparências". Contudo, Dutra (2005) afirma que os positivistas constatam a multiplicidade, diversidade e o caráter contraditório das teorias metafísicas.

Para eles (os Positivistas) apenas o império da positividade dos dados observacionais poderia nos auxiliar na difícil tarefa de separar o certo do errado (DUTRA, 2005).

Porém, mesmo o positivismo pode ser separado em duas vertentes, sendo uma a de Auguste Comte que, embora combatente da metafisica tradicional, defende uma teoria cujo o tema principal é a própria história e o desenvolvimento do espírito humano. E a outra, apresentada em particular por Rudolf Carnap, sendo considerada mais próxima do ideal de manter distância da metafísica (DUTRA, 2005).

\subsection{O Positivisto de Comte ou Tadicional}

A filosofia positiva está atrelada a quatro objetivos principais: pôr em evidência as leis lógicas do espírito humano, promover uma reforma geral na educação, promover o progresso nas diversas ciências e a reorganização da sociedade em bases sólidas. Assim, para cumprir estes objetivos, o positivismo comtiano precisa fundamentar suas afirmações tanto em uma teoria da ciência como em teoria da sociedade.

Para Comte, a base da elaboração de teorias vem de observações prévias, contudo não é possível observar sem uma instrumentalização através de alguma teoria já existente. Aqui entram as concepções ou ficções do estado 
teológico que auxiliam como forma inicial que nos ajudam a fazer observações necessárias para alcançarmos o verdadeiro conhecimento das coisas.

Assim, quando o homem transcende de sua base do conhecimento que vem do teológico para o metafísico, e então, nos atemos a encontrar as relações invariáveis de sucessão e similaridade dos fenômenos, é que alcançamos o objetivo do conhecimento humano (DUTRA, 2005).

Desta forma, apesar do positivismo comtiano ser uma doutrina antimetafísica, observa-se que ela está também fundamentada na mente humana e da própria sociedade que não são decorrências obvias e incontestáveis de observações.

\subsection{O Positivismo de Carnap ou Lógico}

Considerado também como o positivismo lógico ou sistema construcional, Carnap o projetou com um duplo objetivo: legitimar conceitos ou objetos que farão parte da ciência unificada, e eliminar outros conceitos encontrados nas teorias metafísicas tradicionais. Segundo o filósofo este sistema é constituinte da ciência unificada, e o que fica fora dele é considerado metafísico, ou seja, desprovido de significado.

Segundo Dutra (2005) a base desta sintaxe lógica é a Teoria dos Tipos. Segundo ela os erros lógicos se devem ao fato de um enunciado predicar sobre um nível não-apropriado, sem respeitar os tipos lógicos. Assim, o problema visto por Carnap nos enunciados metafísicos não é de caráter semântico, mas sintático ou lógico.

Não se trata de encontrar aquelas coisas às quais se referem os termos empregados pelos metafísicos, mas de mostrar que seus próprios enunciados deixam de ter significado em virtude de erros lógicos (DUTRA, 2005).

Por esta visão de Carnap seu positivismo é alvo de críticas principalmente por adotar critérios epistemológicos estritos, onde a metafísica tradicional e as ciências empíricas seriam eliminadas, o que seria contrário ao pensamento positivista. Por este motivo o filósofo modificou algumas de suas posições em suas obras posteriores. Como no caso de adotar uma base fisicalista em vez de fenomenalista, e de considerar a testabilidade dos enunciados e não apenas suas verificabilidade (DUTRA, 2005). Posteriormente o filósofo complementa sua lógica com uma base mais indutiva, adotando a prática probabilística para isso.

De forma geral, o positivismo não deve ser considerado um desafio à metafísica ou a filosofia tradicional por defender que o único conhecimento legítimo seria aquele que se restringe à experiência. A ideia é que o conhecimento humano não pode abrir mão das observações como uma base privilegiada no 
apoio a qualquer teoria, mas que esta deve contar com o apoio de fatos para ser sustentada.

Neste contexto a metodologia TxM de branding, particularmente em seu processo de definição do "DNA" da marca, aplica ferramentas e técnicas que caracterizam-se tanto com base em fatos como resultados oriundos da intuição. Desta forma, para analisar estes procedimentos, a seguir será apresentada esta metodologia discutindo seus procedimentos com base no positivismo.

\section{Metodologia TXM}

O тхм é a metodologia de Branding que vem sendo desenvolvida no Laboratório de Orientação da Gênese Organizacional da Universidade Federal de Santa Catarina (LOGO UFSC). Esta metodologia tem por objetivo a criação e o desenvolvimento de identidades de marcas de forma cocriativa, ou seja, integrando além dos designers nesta construção, os representantes da empresa que dá suporte a referida marca.

A sigla тхм refere-se aos temos em inglês think (pensar) experience (experiência) e manage (gerir). Cada uma dos três termos representa uma etapa no desenvolvimento da identidade da marca, sendo que cada uma destas subdivide-se em outras sub-etapas.

A primeira etapa - think - será a referente a conceituação da marca. Desta fazem parte ainda outras quatro etapas: Brand DNA Process $^{\circledR}$, definição do propósito da marca, definição do posicionamento de marca e naming. Nesta primeira etapa busca-se principalmente estabelecer as bases conceituais que direcionarão a construção da identidade sensorial (sua parte tangível) e as estratégias de atuação da marca no mercado.

A segunda etapa - experience - abrange a construção de uma marca mais completa. Nesta etapa realiza-se a construção da identidade sensorial, ou seja a que será percebida pelo público através dos sentidos: visão, tato, paladar, olfato e auditiva. Por fim, a terceira etapa - manage - visa a construção de estratégias de atuação da marca no mercado, a partir da conceituação, alinhando estes conceitos os diferentes pontos de contato da marca e as mídias a cada um deles relacionados, no sentido de fortalecer a presença da marca. Assim como, contar a história da marca de forma concisa.

Por ser considerada a base da metodologia тхм, e como discutido anteriormente, o artigo irá apresentar, com base no positivismo, os elementos de construção do - DNA - de marca, relatados por Stodieck e Gomez (2012). 


\subsection{DNA de Marca (Think)}

Segundo Stodieck e Gomez (2012), o "DNA" de uma marca pode ser compreendido como analogia ao mesmo componente nos seres vivos, onde o que irá diferenciar uma marca de outra são suas características particulares.

O "DNA" de uma marca é, assim como nos seres vivos, o que diferenciará uma marca de outra, é formado por diversas características próprias que ao se ligarem, formam um conceito único e diferencial, de onde serão construídas todas as estratégias e posicionamento da mesma (Stodieck e Gomez, 2012)

Assunção et al. (2011, p.01) complementa o pensamento ao relatar que "a metáfora do Brand DNA é assimilar características exclusivas capazes de criar um diferencial com todos os outros concorrentes". Neste sentido, Upshaw (1997) refere-se a marca como o "DNA" corporativo e a representação dele seria sua imagem, assim o "DNA" da marca representa a sua essência, e por isso, deve estar presente em todas as formas de expressão da marca, para que esta marca adquira maior poder de fixação na mente do consumidor (Elwood, 2004).

Deste modo, o diagnóstico do "DNA" de marca deve ser obtido a partir de critérios predefinidos, uma vez que este resultado irá nortear as estratégias de comunicação que levarão ao reconhecimento da marca pelo mercado e seu público.

Segundo Stodieck e Gomez (2012) o processo de geração do "DNA" de uma marca deve seguir as seguintes etapas de projeto:

- PESQUisa preliminar: Etapa inicial das atividades do Brand DNA process ${ }^{\circledR}$. Nela se dá o reconhecimento da visão e missão da empresa além da coleta de outras informações referentes à comunidade da organização;

- Diagnóstico: Etapa onde se traça o diagnóstico da empresa, através da coleta de informações efetiva por meio de entrevistas semi-estruturadas, debates e conversas com os gerentes e os principais stakeholders da empresa, que visam definir as expectativas e percepções em relação à marca;

- ANÁLISE SWOT: Listagem das informações declaradas pelos stakeholders durante as entrevistas. Todas estas informações e também possíveis conclusões serão colocadas num quadro que define pontos internos positivos e negativos da organização, pontos fortes (Strengths) e pontos fracos (Weakenesses), e pontos externos que possam ser compreendidos como Ameaças (Threats) e Oportunidades (Opportunities), e, a partir de então, traçar diagonais que unam conceitos internos e ex- 
ternos, visando estratégias de defesa e de posicionamento. O objetivo desta etapa é gerar diretrizes para a próxima;

- evento Criativo: Etapa em que se organiza um evento criativo, com a participação dos gestores do Brand DNA Process ${ }^{\circledR}$, stakeholders e opinion makers da empresa, onde é aplicada a ferramenta Brand DNA Tool ${ }^{\circledR}$ onde chega-se através de um brainstorming e discussões sobre cada conceito aos possíveis genomas que irão compor o "DNA" da empresa. Após o evento, ainda é realizado nesta etapa a construção do mapa semântico;

- VAlidação: Após o evento criativo, cada participante do evento deve enviar imagens que representem os conceitos do "DNA" para a criação de um painel semântico dos conceitos que formam o "DNA" apresentado na etapa anterior. Em seguida cada um dos participantes do evento é entrevistado individualmente com o intuito de saber se concordam ou não com os conceitos e o que mudariam caso não concordem. Durante a etapa, é feito o benchmarking dos conceitos buscando marcas que representem cada um destes conceitos e estudando seus posicionamentos e estratégias;

Por fim, o resultado de todas estas etapas é organizado em forma de um relatório final personalizado para cada cliente apresentando o "DNA" da marca assim como todas as análises realizadas durante o processo. Ao final de cada relatório, com o "DNA" da marca definido, parte-se para a etapa de posicionamento e estratégia de marca, transformando essas teorias em ações de marca, para que a empresa possa assumir a identidade de sua marca.

\section{Análise do "DNA" de marca sob o ponto de vista Positivista}

Com base no pensamento positivista e nas etapas desenvolvidas para chegar a um "DNA" de marca, observando a tabela 1, obtemos um panorama geral se os resultados destas etapas estão fundamentados por fatos, como no positivismo ou ao contrário, por intuição

\begin{tabular}{|l|l|}
\hline ETAPA DNA PROCESS & PERCEPÇÃO POSITIVISTA \\
\hline PESQUISA PRELIMINAR & FATOS \\
\hline DIAGONÓSTICO & FATOS \\
\hline ANÁLISE SWOT & FATOS / INTUIÇÃO \\
\hline EVENTO CRIATIVO & INTUIÇÃO \\
\hline VALIDAÇÃO & FATOS / INTUIÇÃO \\
\hline
\end{tabular}

Tabela 1. Percepção com base na filosofia positivista com relação as etapas do DNA Process. Fonte: Autores 
Na fase da pesquisa preliminar, uma vez que são realizados uma série de levantamentos de informações de forma qualitativa como a busca pela visão e missão da empresa e a coleta por inúmeras informações sobre a organização que sejam pertinentes ao desenvolvimento do processo. Entende-se esta etapa do Brand DNA Process como sendo baseada totalmente em fatos, uma vez que as informações são recebidas pelas steakholders e analisadas pela equipe de especialistas no assunto que está aplicando o processo. Estas informações são coletadas a partir de entrevistas realizadas, e as respostas são posteriormente analisadas, discutidas e verificadas com informações pré adquiridas por meio de pesquisas em base teórica em material bibliográfico de autores, pesquisadores especializados no assunto. Todas estas informações são cruzadas para definir a percepção que a marca irá adotar na percepção das pessoas na etapa de Diagnóstico.

A segunda parte do Brand DNA Process ${ }^{\circledR}$ pode ser classificada como baseada em fatos pois tem a função de estruturar e classificar as informações vindas da primeira etapa e também tem a função de gerar entendimento para a etapa de Análise Swot, que compõe a terceira etapa. Nesta análise, que inclui os pontos fortes, fracos, ameaças e oportunidades, da marca em relação ao seu ambiente interno e externo, pode-se entender que é classificada em fatos e utiliza também a intuição na sua elaboração, uma vez que inclui-se pesquisas ou dados já publicados, mas também utiliza-se de ferramentas intuitivas na definição de alguns pontos e no cruzamento de informações para gerar previsões de estratégias de atuação para a marca.

Já o resultado da etapa denominada de "Evento Criativo", pode ser entendido como unicamente elaborada a partir da intuição dos participantes, pois, durante o processo de brainstorm as pessoas envolvidas nem sempre tem o conhecimento amplo sobre o assunto e também pelo fato desta técnica ser utilizada para gerar grande número de informações e ideias possíveis, sem necessariamente serem comprovados.

Por último aplica-se a etapa de "Validação", que pode ser entendida como uma etapa que se utiliza tantos de fatos como da intuição, pois os dados são apresentados de modo visual em um painel semântico de forma já utilizada em outras metodologias, e com referencial teórico sobre este assunto, para todos os participantes e tem a função de "reafirmar" os conceitos já pré-estabelecidos, definindo assim a parte intuitiva do processo. 


\section{Conclusões}

Pode-se observar, a partir deste estudo que as pesquisas projetuais e as pesquisas científica estão sempre interligadas e podem convergir para um mesmo objetivo. Em diversos momentos observa-se também que a pesquisa científica, como definida no positivistmo, pode ser utilizada como base de apoio para a metodologia projetual, ou seja, a parte mais executiva de um processo. Esta explanação fica evidente na metodologia do Brand DNA Process por contar com uma base cientiífca na busca de fatos que levem ao resultado final.

Observou-se que em diversos momentos do Brand DNA Process ${ }^{\circledR}$ existe uma busca e a utilização com base em dados científicos, principalmente nas etapas de pesquisa preliminar e de diagnóstico, onde toda a base para a execução destas etapas estão ligadas as pesquisas científica destacando assim a percepção positivista na construção da metodologia.

Assim, pode-se afirmar que este processo por vezes necessita de apoio em uma metodologia de pesquisa. Pois, por ser um processo tanto aplicado no meio acadêmico como mercadológico, fica necessário comprovar seus resultados.

\section{Referências}

ASSUNÇÃO, H.; GOMEZ, L.S.R., REIS, P. F. C; STODIECK, W. F. DNA de marca: Um estudo prático do processo de identificação. e-Revista LOGO. Florianópolis, v.II, 2011.

BONSIEPE, G. Design, cultura e sociedade. São Paulo: Blucher, 2011.

BÜRDEK, B. E. Design: história, teoria e prática do design de produtos. $2^{a}$.ed. São Paulo: Blucher, 2010.

DUTRA, L. H. de A. Oposições filosóficas; a epistemologia e suas polêmicas. Florianópolis: Editora da UFSC, 2005, 191p.

FACCA, C. A. O designer como pesquisador: uma abordagem metodológica da pesquisa aplicada ao design de produtos. 2008. 213p. Dissertação (Mestrado em Design arte e Tecnologia) - Uiversidade Anhembi Morumbi. São Paulo, 2008.

VERDAN, A. O ceticismo filosófico, Trad. Jaimir Conte. Florianópolis: Editora da UFSC, 1998, 135 páginas. 
STODIECK, W. F. e GOMEZ, L. S. R. A Utilização do Brand DNA Process na Criação de uma Marca de Empresa de Cervejas Diferenciadas. 10 $^{\circ}$ Congresso Brasileiro de Pesquisa e Desenvolvimento em Design, São Luís (MA), 2012. Upshaw, L. B. Transferable trhths of brand identity. Design Management Journal, p. 9-14, 1997.

ELLWOOD, I. O livro essencial das marcas: tudo o que você precisa saber, em mais de 100 técnicas, para aumentar o valor das marcas. Tradução: Henrique Amat Rêgo Monteiro. São Paulo: Clio, 2004. 
Recebido em: 26/04/2014

Aceito em: 01/06/2014

\section{Como citar}

BRAUN, Jan Raphael Reuter; LOPES, Dayane; WERNER, Leandro; PERASSI, Richard; GOMEZ, Luiz Salomão Ribas. O positivismo percebido nas etapas de desenvolvimento do DNA da marca. Arcos Design. Rio de Janeiro: PPD ESDI - UERJ. Volume 8 Número 1 Junho 2014. pp. 36-48. Disponível em: [http://www.epublicacoes.uerj.br/index.php/arcosdesign]

\section{DOI}

http://dx.doi.org/10.12957/arcosdesign.2014.13020

\section{(c) (1) (2)}

A Revista Arcos Design está licenciada sob uma licença Creative Commons Atribuição - Não Comercial - Compartilha Igual 3.0 Não Adaptada. 